\title{
The Faith that Does Prudence: Contemporary Catholic Social Ethics and the Appropriation of the Ethics of Aquinas
}

\author{
Brian Reedy, SJ* \\ Boston College School of Theology and Ministry
}

Under the umbrella term of "social justice" the contemporary Society of Jesus is committed to the analysis and changing of the social and economic structures that impact human lives, so that the values of the Gospel can be actualized within the human family. Understanding what Aquinas has to say about the issues involved in social justice is important for two reasons. First, the theological and ethical language of the Society, and the Catholic Church in general, draws deeply from the Thomistic tradition. Second, there is a vigorous resurgence of attempts to reappropriate Aquinas' ethical theory according to contemporary sensibilities. For all those interested in promoting social justice within a Catholic framework it is important to understand how the issues related to social justice relate to Aquinas' theological project. Although Aquinas does provide a theoretical framework in which the issues of social justice can be addressed, he provides a different rubric. The contemporary convictions of radical equality and individual rights belong to the Thomistic domain of theoretical reasoning through wisdom. The critique and evaluation of social structures according to contemporary economic theories and sensibilities belongs to the Thomistic domain of practical reasoning through prudence. The commitment to the preferential option for the poor belongs to the Thomistic virtue of charity. In Aquinas' language, the faith that does justice is, because it acts in a critical and constructive fashion, more accurately a faith that acts prudently.

\footnotetext{
* Brian Reedy, SJ currently serves as a deacon at St. Paul's Parish in Cambridge, MA. He is finishing an MDiv and an STL that focuses on Aquinas at the Boston College School of Theology and Ministry. He holds master's degrees in philosophy from Fordham University and in chemistry and biophysics from Texas A\&M University. His interests include the intersection of religion, philosophy, and science.
} 


\section{Introduction}

One of the most important contemporary issues within the Society of Jesus is the way in which contemporary evangelization impacts social evolution and social structures. Under the umbrella term of "social justice," the Society is committed to analyzing and changing social and economic structures that impact human lives so that the values of the Gospel can be actualized within the human family. Understanding what St. Thomas Aquinas has to say about the issues involved in social justice is important for two reasons. First, the theological and ethical language of the Society, and the Catholic Church in general, draws deeply from the Thomistic tradition. Many of the categories and much of the language used to discuss ethical and political issues are drawn from Aquinas' theory. Therefore, understanding our traditional formulations and our patrimony of ethical reasoning requires an understanding of his theory.

Second, there is a vigorous resurgence of attempts to reappropriate Aquinas' ethical theory according to contemporary sensibilities, because his treatment of the human agent as a deeply contextualized and organically related person is very attractive. The theory of virtue ethics, which he adapted from Aristotle, promises to help ethicists navigate out of many of the rocky waters produced by deontological methods or by philosophical perspectives that treat the agent as acting from a place of Cartesian isolation. The recontextualization of the human agent within a robust and organic account of human experience, the fluid and dynamic perspective of the virtues, and the rational principles outlined in natural law theory all serve as points of interest in contemporary ethics, especially for Roman Catholic ethicists. Therefore, understanding how to move forward and engage current ethical theories is also assisted by an astute grasp of Aquinas' ethics.

For all those interested in promoting social justice within a Catholic framework it is important to understand how social justice issues relate to Aquinas' theological project. The constellation of issues commonly referred to as the promotion of social justice includes: 1) the acceptance of a radical equality for all human persons and a protection of the rights of individuals in relationship to various subgroups or the overall society; 2) a critique of social and economic structures such that there can be an equal access to goods, services, and opportunities for all people; and 3) a commitment to the preferential option for the poor. While we consider these criteria necessary for promoting social justice we are using the term "justice" in a manner that is quite different from Aquinas. To understand how Aquinas' ethical theory can be applied to contemporary social justice one must recognize how the term justice has changed through time. One must also realize that, although Aquinas does provide a theoretical framework in which the issues of social justice can be addressed, he does so employing a different rubric. The contemporary convictions of radical equality and individual rights belong to the Thomistic domain of theoretical reasoning through wisdom. The critique of social structures according to contemporary economic theories and sensibilities belongs to the Thomistic domain of practical reasoning through prudence. The commitment to the preferential option for the poor belongs to the Thomistic virtue of charity. In Aquinas' language, the faith that does justice is, because it acts in a critical and constructive fashion, more accurately a faith that acts prudently. To see how 
this is the case we must first elucidate how Aquinas envisions the human person acting, how he relates the faculties of intellect and will, and how these are perfected by the virtues of prudence and justice.

\section{Overarching Structure of Aquinas’ Ethics}

Aquinas' ethical theory attempts to account for every aspect of the human act. Aquinas envisions people as creatures, situated in a specific social and environmental framework, possessing intellect and will, and drawn towards the goals that attract them. Properly human actions, or moral actions, are the voluntary movements towards a goal that is perceived as good. According to Aquinas, people move toward that which perfects and fulfils them by nature.

Aquinas understands the process of human development as one of intentional becoming. Human flourishing, or happiness, is not given from the start but is a goal towards which we are supposed to deliberately move. For people to act ethically, and to move towards happiness, they must have a correct intellectual grasp of what human life is supposed to be, what flourishing looks like, and have a rightly ordered will such that they desire this proper end. The healthy human person acts as a single, whole unit, and not with competing faculties that cause a schizophrenic duplicity or multiplicity in the self. However, in his discussion of the pursuit of happiness, Aquinas employs the distinction between intellect and will, and of these two he gives priority to the intellectual apprehension, and the articulation of our nature and state of affairs described by happiness:

Two things are needed for happiness: one, which is the essence of happiness: the other ... [is] the delight connected with it. I say, then, that as to the very essence of happiness, it is impossible for it to consist in an act of the will. For it is evident from what has been said ${ }^{1}$ that happiness is the attainment of the last end. But the attainment of the end does not consist in the very act of the will. For at first we desire to attain an intelligible end; we attain it, through its being made present to us by an act of the intellect; and then the delighted will rests in the end when attained. So, therefore, the essence of happiness consists in an act of the intellect: but the delight that results from happiness pertains to the will. ${ }^{2}$

According to Aquinas, the intellectual appetite for truth moves us to investigate our nature and to form principles of understanding by which we can know how to move towards the end that our nature suggests. The intellect then presents a possible course of action that will facilitate movement towards the end. The job of a well-ordered will is to choose both the ends and the means presented by the intellect, and to delight in the state of affairs as much as it contains the happiness according to our last end.

\footnotetext{
${ }^{1}$ St. Thomas Aquinas, The Summa Theologica of St. Thomas Aquinas, Second and Revised Edition (1920), Online Edition (2008): http://www.newadvent.org/summa, I-II, Q2, A7.

${ }^{2} S T$, I-II, Q3, A4.
} 
Aquinas states that the action of the intellect, i.e. reasoning, can be understood as having two different aspects, or as working in two different ways. The first way he calls theoretical reasoning and the second he calls practical reasoning. Theoretical reasoning is concerned with the comprehension of natures, forms, and principles. It is, therefore, abstract and speculative. Theoretical reasoning investigates the issues surrounding human flourishing. It is responsible for apprehending our human nature, articulating the principles that flow from said nature, and relating our nature to the social and environmental structures in which we live. In short, theoretical reasoning applies to the entire intellectual analysis of what it means to be human and to the logical conclusions that can be drawn from such analysis. Theoretical reasoning concerning human nature gives rise to a conceptual articulation of what human flourishing and happiness look like according to the final ends of the human person. Since the human person is a social, embodied, and situated creature, the articulation of theoretical reasoning as pertains to human nature necessarily includes definitions of the ideal states of various human interpersonal relationships, relationships to various external goods, and other issues surrounding the human situation. The conceptual analysis and investigation of the functions of state, family, matrimony, and economy, for example, is in principle the proper domain of theoretical reasoning.

Practical reasoning is concerned with applying the conclusions and conceptual articulations of theoretical reasoning to specific situations. Practical reasoning, when applied to the issues surrounding human flourishing, is responsible for ascertaining the means by which the ends, as articulated by theoretical reasoning, can best be achieved. It is focused on practical concerns and operates within the sphere of the "real world" of experience, finitude, and limitation. For Aquinas, practical reasoning begins with general principles immediately recognized by the intellect as true. These principles are comprehended according to the virtue of synderesis, which is a disposition of the intellect such that it can grasp fundamental principles of human action. ${ }^{3}$

Building upon on the basic principles of action grasped through the virtue of synderesis, practical reasoning then makes judgments about what sort of actions should be taken, according to the circumstances, towards the intended goal. Again, since the human person is a social, embodied, and situated creature, the articulation of practical reasoning as applied to specific situations necessarily includes specific means of organizing and practically living within the various human interpersonal relationships, relationships to various external goods, and other

\footnotetext{
${ }^{3}$ The principles of action grasped by synderesis are not a priori knowledge contained in the soul, but principles of action arrived at by experience. An example Aquinas gives of such a principle is "good is to be done, and evil avoided." Although Aquinas does not develop the concept of synderesis as much as I would hope in the Summa, he does speak a little more succinctly in another document concerning the virtue: "Thus, just as there is a natural habit of the human soul through which it knows principles of the speculative sciences, which we call understanding of principles, so, too, there is in the soul a natural habit of first principles of action, which are the universal principles of the natural law. This habit pertains to synderesis" (St. Thomas Aquinas, Questiones Disputatae de Veritate, html edition by Joseph Kenny, O.P., English translation: http://dhspriory.org/thomas/QDdeVer.htm, 16, 1). Interestingly, according to Aquinas, the virtue of synderesis produces principles of action that are infallible (De Ver., 16, 2). It can be, therefore, deduced that the scope of such principles is quite limited since Aquinas does not propose much inerrancy in human action.
} 
issues surrounding the human situation. The practical day-to-day functioning of the relationships of state, family, matrimony, economy, etc., is the proper domain of practical reasoning.

Once a course of potential means of action is selected through practical reasoning, the moral agent exercises conscience whereby moral conclusions are drawn about the relative goodness or badness of the act in question. ${ }^{4}$ According to Aquinas, one must act according to the dictates of conscience, that is, according to what is judged as good and right, even if the judgment is faulty because of inept or ineffective reasoning. In fact, it would be a moral evil for a well-ordered will to act against reason even if that reason is faulty. Aquinas concludes, "absolutely speaking, every will at variance with reason, whether right or erring, is always evil."5 This absolute dependence of the will upon proper reasoning emphasizes the importance of Aquinas' system of virtues by which the intellect, and therefore reasoning, can be improved or perfected. Aquinas assigns three virtues that attend and perfect theoretical reasoning and two that relate to practical reasoning. The virtues that deal with theoretical reasoning are understanding, science, and wisdom. The virtues that attend and perfect practical reasoning are art and prudence. ${ }^{6}$

\section{The Virtue of Prudence}

It is important to keep in mind that for Aquinas the distinctions and definitions, faculties and habits, and the various aspects of the human person are never absolutely distinct but always acting in concert in the unified human person. Therefore, although we are going to focus our attention on how it is that the virtue of prudence acts upon and perfects practical reasoning, it is not to be thought of as exercising its habit apart from the rest of the virtues and faculties. All of the virtues impact one another and work in concert with the faculties of the soul in the process of human flourishing; nevertheless, prudence has primacy of place among them. While discussing the cardinal virtues of prudence, justice, temperance and fortitude, he says:

It may also be said that these four virtues qualify one another by a kind of overflow. For the qualities of prudence overflow on to the other virtues in so far as they are directed by prudence. And each of the others overflows on to the rest, for the reason that whoever can do what is harder, can do what is less difficult. ${ }^{7}$

\footnotetext{
${ }^{4}$ According to Aquinas, conscience is not a moral virtue but simply the judgment we may come to concerning a specific act, in light of various rational concerns of practical reasoning. The exercise of conscience and the practical application of reasoning to a specific situation are vulnerable to error: "As is clear from what has been said, conscience is nothing but the application of knowledge to some special act. Error, however, can occur in this application in two ways; in one, because that which is applied has error within it, and, in the other, because the application is faulty" (De Ver., 17, 2).

${ }_{6}^{5}$ ST, I-II, Q19, A5.

${ }^{6}$ Although this paper would benefit from a thorough discussion of the virtue of wisdom and how it relates to and perfects theoretical wisdom, that discussion would easily turn this research paper into a full thesis. Suffice it to say that wisdom, when applied to the articulation of the common good presented by theoretical reasoning, describes the other major access point for a critical appropriation of Aquinas' social theory.

${ }^{7}$ ST, I-II, Q61, A4.
} 
The English word prudence, which is used to translate Aquinas' virtue prudentia, has many different definitions. ${ }^{8}$ In its current usage it carries some negative connotations, some of which can be detected in such synonymous terms and phrases as: caution, discretion, regard for one's own interest, wise management, or frugality. For Aquinas, the word we translate into English as "prudence" does not contain the negative tenor that contemporary English has gained; therefore, understanding how Aquinas uses the term requires that we set aside the contemporary usage and strive to understand the word as he defines it. Aquinas provides the most complete definition of prudence in his treatment of the intellectual virtues:

Prudence is a virtue most necessary for human life. For a good life consists in good deeds. Now in order to do good deeds, it matters not only what a man does, but also how he does it; to wit, that he do it from right choice and not merely from impulse or passion. And, since choice is about things in reference to the end, rectitude of choice requires two things: namely, the due end, and something suitably ordained to that due end. Now man is suitably directed to his due end by a virtue which perfects the soul in the appetitive part, the object of which is the good and the end. And to that which is suitably ordained to the due end man needs to be rightly disposed by a habit in his reason, because counsel and choice, which are about things ordained to the end, are acts of the reason. Consequently an intellectual virtue is needed in the reason, to perfect the reason, and make it suitably affected towards things ordained to the end; and this virtue is prudence. ${ }^{9}$

While theoretical reasoning produces a description of what human flourishing and happiness looks like, the means for moving towards the goal of happiness within the context of the common good are developed and presented through the exercise of practical reasoning assisted by prudence. Therefore, the specific ways in which the common good can be expressed in laws and social structures, that is, how the universal principles contained in the theoretical presentation of human flourishing and the common good can be applied within a specific set of circumstances, is the domain of practical reasoning assisted by prudence.

Prudence is one of the most crucial virtues for human flourishing and the pursuit of happiness because it has an effect in both the intellectual and moral domains. It is a bridge virtue, and not only does it have the ability to impact both practical and moral reasoning but it serves to unite many aspects of human action. Aquinas demonstrates the simultaneous interconnectedness and primacy of prudence over the other virtues:

The end concerns the moral virtues, not as though they appointed the end, but because they tend to the end which is appointed by natural reason. On this they are helped by prudence, which prepares the way for them, by disposing the means. Hence it follows that prudence is more excellent than the moral virtues, and moves them. ${ }^{10}$

\footnotetext{
${ }^{8}$ One of the central difficulties in translating or understanding this word as Aquinas uses it is that he translated Aristotle's Greek word phronesis, which can be understood as "practical wisdom," into the Latin prudentia which carries the connotation of foresight among other things.

${ }^{9} \mathrm{~S} T$, I-II, Q57, A5.

${ }^{10} \mathrm{ST}$, II-II, Q47, A6.
} 
Daniel Mark Nelson, in his thesis, Priority of Prudence, states that Aquinas' ethical theory is not primarily a theory of the natural law, but of virtue in which the organizing dynamic is that of practical reason acting with prudence. Although Nelson overemphasizes prudence, and thereby relativizes and marginalizes other virtues and the need for grace, he correctly identifies the central place of prudence in Aquinas' conceptualization of the human act. Nelson points out that the two aspects of Aquinas' thought that are often used to guide ethical discourse and that dominate the contemporary appropriations of his ethical system. These aspects are the principles of natural law and the subsequent "socialization" of these principles through the virtue of justice, by which the human person becomes connected to other people. The emphasis on these two features, Nelson argues, fails to properly appreciate the role of prudence in Aquinas' system. It is clear that, for Aquinas, the virtue of prudence and its context of practical reasoning presume the social context of the human agent and include the relationships therein. One does not have to invoke justice to connect the virtuous person to other people. Aquinas states clearly that prudence governs the human person in all of his or her relationships:

Wherefore there must needs be different species of prudence corresponding to these different ends, so that one is "prudence" simply so called, which is directed to one's own good; another, "domestic prudence" which is directed to the common good of the home; and a third, "political prudence," which is directed to the common good of the state or kingdom. ${ }^{11}$

Practical reason is guided by prudence to the correct and appropriate means by which the common good can be achieved. Therefore, the particular characteristics of social institutions, laws, social structures, and the like are the practical applications and manifestations of the ideas and principles of the common good as presented and expressed through theoretical reasoning. For Aquinas, as for Aristotle, the relationship of the individual to the society is one of part to whole, and imperfect to perfect. Therefore, the flourishing and happiness of the individual person is inextricably bound up with the common good and universal happiness presented in the wellordered society:

Moreover, since every part is ordained to the whole, as imperfect to perfect; and since one man is a part of the perfect community, the law must needs regard properly the relationship to universal happiness. Wherefore the Philosopher, in the above definition of legal matters mentions both happiness and the body politic: for he says that we call those legal matters "just, which are adapted to produce and preserve happiness and its parts for the body politic": since the state is a perfect community. ${ }^{12}$

It is according to the conclusions of practical reasoning guided by prudence, which are themselves circumstantial manifestations of the universal principles defined by theoretical reasoning, that society is governed and that the relationships between individuals are defined and oriented towards the common good.

\footnotetext{
${ }^{11} S T$, II-II, Q47, A11.

${ }^{12} S T$, I-II, Q90, A2.
} 


\title{
The Virtue of Justice
}

It is immediately after the discussion of the virtue of prudence that Aquinas turns his attention to the virtue of justice. He has already discussed how it is that theoretical reasoning, assisted by wisdom, comprehends human nature and articulates principles of flourishing that include the relationship of individuals to society. In his discussion of prudence it seems that the virtue guides and perfects practical reasoning such that the common good and human flourishing described by theoretical reasoning, according to human nature, can find expression in the real world and become manifest through social structures, laws, and practical application. It is then the duty of the virtue of justice to move the will of the person to choose to give each person his or her due according to the common good as articulated by theoretical reasoning. Aquinas offers the basic definition of justice as the disposition of the will "to render to each one his due." What each person is due is defined by reason - theoretical reason defining the principles of what is due, and practical reason defining the particulars. Aquinas makes it clear that justice does not aim at directing an act of the intellect, but of the will:

\begin{abstract}
Now justice does not aim at directing an act of the cognitive power, for we are not said to be just through knowing something aright. Hence the subject of justice is not the intellect or reason which is a cognitive power. But since we are said to be just through doing something aright, and because the proximate principle of action is the appetitive power, justice must needs be in some appetitive power as its subject. Now the appetite is twofold; namely, the will which is in the reason and the sensitive appetite which follows on sensitive apprehension, and is divided into the irascible and the concupiscible...Again the act of rendering his due to each man cannot proceed from the sensitive appetite, because sensitive apprehension does not go so far as to be able to consider the relation of one thing to another; but this is proper to the reason. Therefore justice cannot be in the irascible or concupiscible as its subject, but only in the will. ${ }^{13}$
\end{abstract}

Justice influences the actions of a person by directing his or her actions towards the common good just as charity directs the actions towards the divine good, but the characteristics of both the common good and the divine good are the proper domain of reason. ${ }^{14}$ Since justice is a disposition of the will it does not exercise direct influence on the rational articulations of what exactly each person is due; it simply assists the person to act in accordance with whatever the intellect has decided is due to each according to the right social order. ${ }^{15}$ This is how it is that a person can act justly within a social structure that, when critiqued by another articulation of social order or human flourishing, might be condemned as unjust.

\footnotetext{
${ }^{13}$ ST, II-II, Q58, A4.

${ }^{14}$ ST, II-II, Q58, A6.

15 Aquinas does allow that justice is related to reason through a kind of nearness: "Since the will is the rational appetite, when the rectitude of the reason which is called truth is imprinted on the will on account of its nighness to the reason, this imprint retains the name of truth; and hence it is that justice sometimes goes by the name of truth" (ST, II-II, Q58, A4, Reply to Obj 1).
} 
For instance, many of the social structures that Aquinas engages in the section on justice are now viewed with suspicion or even outright rejection. When discussing whether or not "right is the object of justice," Aquinas presents a theory by which justice functions as a protector of the values ensconced in the social order - a social order that contains elements that contemporary Western culture rejects on the basis of a presumption of radical equality. This presumption is interjected into Aquinas' theory through the selective quoting of the following passage:

It is proper to justice, as compared with the other virtues, to direct man in his relations with others: because it denotes a kind of equality, as its very name implies; indeed we are wont to say that things are adjusted when they are made equal, for equality is in reference of one thing to some other. ${ }^{16}$

This passage is used to suggest that the idea of absolute and universal equality between human persons exists in Aquinas' ethical theory. Taken out of context, it does seem to support such an idea, but one does not have to look far to see that Aquinas is simply not proposing the kind of absolute and universal human equality that is valued highly in much of Western society today. Aquinas qualifies the equality he is referring to by saying: "For the equality of distributive justice consists in allotting various things to various persons in proportion to their personal dignity." 17 Thomas mentions some of the inequalities present in the social theory in which he is operating. As pertains to domestic relations Aquinas speaks of children, wives, and slaves as "belonging to" the father. Aquinas states that, properly speaking, there is not justice between father and son nor master and slave because their relations stand in the context of sharply distinct domestic roles. This flatly contradicts the idea that he believes in a concept of absolute equality. Aquinas does moderate the potential abuse in domestic relationships by offering that justice does exist in domestic relationships "in a way," but in the domestic structure there is not the kind of unqualified justice that exists between true equals. ${ }^{18}$

In this section of his treatment of justice, Aquinas does not address the relationships between men and women extensively; however, Aquinas accepts that women are fundamentally inferior to men and should be governed by them. He formed this opinion using a combination of the Politics of Aristotle and the testimony of Scripture. ${ }^{19}$ In his letter to the Ephesians St. Paul says that "a husband is the head of his wife" and to the Corinthians he states that "man is the

\footnotetext{
${ }^{16} \mathrm{ST}$, II-II, Q57, A1.

${ }^{17} \mathrm{ST}$, II-II, Q63, A1.

18 "It belongs to justice to render to each one his right, the distinction between individuals being presupposed: for if a man gives himself his due, this is not strictly called "just." And since what belongs to the son is his father's, and what belongs to the slave is his master's, it follows that properly speaking there is not justice of father to son, or of master to slave. A son, as such, belongs to his father, and a slave, as such, belongs to his master; yet each, considered as a man, is something having separate existence and distinct from others. Hence in so far as each of them is a man, there is justice towards them in a way: and for this reason too there are certain laws regulating the relations of father to his son, and of a master to his slave; but in so far as each is something belonging to another, the perfect idea of "right" or "just" is wanting to them" (ST, II-II, Q57, A4).

19 Aquinas wrote a commentary on the Politics of Aristotle in which he makes very little criticism of the social theory contained therein. See Commentary on the Politics, trans. Richard J. Regan (Indianapolis: Hackett, 2007).
} 
head of woman." 20 Aquinas concludes from this Scriptural reference that men are intellectually superior to women. The combination of this conclusion with Aristotle's justification of social order through the principles of form and matter in his metaphysical biology formed the foundation of philosophical justification of male superiority for centuries. When he is speaking of the domestic relationship of men and women, Aquinas says:

...For the good order would have been wanting in the human family if some were not governed by others wiser than themselves. So by such a kind of subjection woman is naturally subject to man, because in man the discretion of reason predominates. Nor is inequality among men excluded by the state of innocence, as we shall prove. ${ }^{21}$

The end of the quote indicates that, in addition to the presumed inequalities of the domestic relationships, Aquinas accepts that there are inequalities based on social status or function. There exists a proportionality of what is due to each person according to how they relate to the common good as expressed in the structure of the functioning society:

... the matter of justice is an external operation in so far as either it or the thing we use by it is made proportionate to some other person to whom we are related by justice. Now each man's own is that which is due to him according to equality of proportion. Therefore the proper act of justice is nothing else than to render to each one his own. ${ }^{22}$

For Aquinas there is a kind of equality that exists between all people, but this equality is modified and qualified according to each person's relationship to the social structures that are defined and expressed through reason's attempt to comprehend human nature. It is correct to say that Aquinas was simply expressing justice within his contemporary culture, but this is not helpful in the process of appropriating his ethics. There is no reason, however, to grow embarrassed of his failure to apply the principles of justice to critique the inequalities presumed in his social theory. For Aquinas, justice does not possess this capability. The reason justice is applied in a differential manner and according to basic inequalities of individuals is that the differentials and inequalities are manifestations of the common good that are the result of practical reasoning making manifest the principles of theoretical reasoning applicable to the circumstances of his time.

In order to understand Aquinas, one must understand that social change is not brought about by critiquing social structures, laws, and presumptions according to the virtue of justice. Social change, rather, is accomplished through a critique of social structures, laws, and presumptions according to reason. If one wants to challenge the domestic and public presumptions of inequality, and challenge Aquinas' conceptualization of how individuals relate to the common good, one does not do so on the basis of justice, but on the basis of right-reason giving rise to a new articulation of the common good and human flourishing. Although this process would require the virtue of justice to be present, so that one would remain dedicated to

\footnotetext{
${ }^{20}$ Ephesians 5:23, 1 Corinthians 11:3 (RSV).

${ }^{21} S T$, I, Q92, A1.

${ }^{22}$ ST, II-II, Q58, A11.
} 
choosing that which gives each their due, the virtues responsible for determining what each person is due are wisdom and prudence acting on the intellect. Justice, by contrast, acts upon the will. As stated earlier, the will should not contradict what reason dictates, even if the reasoning is in error.

\section{Contemporary Concepts of Justice}

One of the difficulties in understanding and appropriating Aquinas' ethical theory is language. The contemporary American concept of justice can obscure the specific manner in which the virtue operates in Aquinas' system. Our concept of justice has been informed by the philosophical systems of the influential political and philosophical minds of the $18^{\text {th }}$ through $20^{\text {th }}$ centuries. During these centuries the principle of absolute equality arose and joined forces with a tendency to ascribe specific rights to individuals, as opposed to justifying a concept of right order in society. This combination has served as the basis for the reevaluation of many social presuppositions, structures, and strictures. The contemporary Anglo-American conceptualization of justice has been profoundly impacted by the Rawlsian appropriation of Kant, Rousseau, and Locke. For our conversation, the three pertinent characteristics of Kantian ethics are that: 1) it is deontological and justifies norms of action in terms of rational principles rather than teleological ends; 2) it is formalistic in that it does not explicate natures and substantive moral ideas, but provides a neutral procedure for rational choice; 3) it is universalistic in that its principles are meant to be valid in any human situation as opposed to a specific culture or historical moment. ${ }^{23}$ One can see that this method of ethical discourse is, in many ways, antithetical to the theory presented by Aquinas.

In his Theory of Justice Rawls builds on the presuppositions of Kant and provides a procedure for assessing principles of justice that is both neutral with respect to the different conceptions of the good and independent of the values and interests of particular groups or communities. Rawls begins with the statement, "Justice is the first virtue of social institution." 24 He says that a good society is one structured according to principles of justice. Rawls asserts that existing theories of justice, developed in the field of philosophy, are inadequate: "My guiding aim is to work out A Theory of Justice that is a viable alternative to these doctrines which have long dominated our philosophical tradition." ${ }^{25} \mathrm{He}$ emphasizes that the principles of justice should not take into account any possible differences among individuals. Moral reasoning is to be guided by choosing principles of justice from behind a "veil of ignorance." This point of view, which he calls the "original position," is intended to ensure that the principles of justice selected are intentionally ignorant of historical and societal contexts, including history, society, race, sex, class, wealth, assets, abilities, values, or conceptions of the good. Justice, therefore, is

\footnotetext{
${ }^{23}$ Drawn from: Georgia Warnke, Justice and Interpretation (Cambridge, MA: The MIT Press, 1993), 1-3.

${ }^{24}$ John Rawls, A Theory of Justice (Cambridge, MA: Harvard University Press, 1971), 3.

${ }^{25}$ Ibid.
} 
a virtue that seeks to guide moral reasoning according to an absolute claim of universal equality. For Rawls, justice is not an inclination of the will to act in support of the social distinctions that are manifestations of reason's articulation of the common good according to some rational apprehension of human nature. Rather, it is a virtue with a deeply rational character, by which absolute and radical equality is made manifest in social order.

The Kantian-Rawlsian approach is, of course, quite different from the way in which Aquinas understands the virtue of justice to be operating. For Rawls there can be principles of justice which function specifically to critique and reform social structures according to a fundamental conviction of universal and absolute equality. For Aquinas the primary function of justice is to protect and ensure the stability of society by reinforcing the need to give to each person according to their relative position in society, with specific regard to the very differences to which Rawls was blind, and to express a particular view of the common good. For Aquinas justice is a fundamentally conservative virtue that preserves the social order. Since it is located in the will, it is not the proper virtue to empower social critique or change. Although the dedication of the will toward seeking that which "gives others their due" is an integral part of any rational exploration of social structure, it plays only a supporting role. It is clear that our concept of justice has changed significantly and that we must be aware of these changes if we are to successfully understand Aquinas' theory.

\section{Evolution of Social Justice}

The Kantian-Rawlsian impact on our current understanding of justice is not the only change that needs attention for a contemporary Catholic appropriation of Aquinas. One of the ways in which justice is commonly discussed in Catholic circles, and certainly among Jesuits, is within the context of promoting social justice. The social encyclicals of the Church and the documents of the Society of Jesus both show a rise in the concern for and dedication to social justice. Thomas Burke, in his article on the "Origins of Social Justice", traces the development of the phrase from the writings of a $19^{\text {th }}$ century Jesuit scholar to the present. According to Burke, the term "social justice" was coined by Jesuit Fr. Luigi Taparelli d'Azeglio in 1843. Taparelli used the term in the Thomistic fashion according to which justice is the virtue by which the social order was protected because by it the virtuous person would give to other people according to their proper place within a naturally structured society. Although Taparelli, like Aquinas, did not explicitly support one schema of social organization over another, he presumed that the social order arose out of natural differentiation between people. God has given all people the desire to seek the supreme good and to do so in a cooperative and social manner. Taparelli openly rejects both the Lockean principle of equality and what he calls the "historical fiction of the social contract. ${ }^{, 26}$ He posits that there is natural authority according to relative prowess:

\footnotetext{
${ }^{26}$ Thomas Patrick Burke, “The Origins of Social Justice: Taparelli d'Azeglio,” Modern Age 52:2 (Spring 2010 ): 99.
} 
Authority...arises because some men are naturally braver, more competent, more intelligent, wealthier, or better endowed with the qualities of leadership than others. When a particular authority grows so strong that it has no superior it attains to sovereignty, and if it exists in a stable territory it becomes a state. The right to govern a state... belongs to the person who has established order in it. ${ }^{27}$

For Taparelli, social justice requires that one recognize that natural inequalities exist among people and to accept that it is due to these inequalities that natural government develops. Social justice, therefore, is a conservative virtue by which these structures of government are recognized as having legitimacy and each person supports the social structure according to his or her place within the society ordered - i.e. made right-by the exercise of authority.

According to Burke, the ironic turn in the history of the phrase "social justice" occurred when it was connected to Taparelli's economic theory-which was also fundamentally conservative. Taparelli defended what he considered the more "communitarian economics" of Catholicism against what he considered the "individualistic economics" of Protestant countries. Taparelli argues that economic structures must exist for the advancement of the common good and not for personal gain or private accumulation of wealth. Although Taparelli never uses the phrase "social justice" with respect to his economic theory, the two theories, both fundamentally conservative in his context, were amalgamated as they were appropriated. Social justice gradually came to mean the virtue by which social structures and economic policies were evaluated. The concerns voiced by Taparelli entered official Catholic discourse with the publication of the great social encyclical Rerum Novarum by one of Taparelli's students, Pope Leo XIII, in 1891. The phrase itself was first used officially by the Church in 1931 when the encyclical Quadragesimo Anno was published. In this document, somewhat ironically in light of the background in Taparelli's views, the phrase "social justice" is used explicitly as a virtue by which social and economic structures are evaluated according to a principle of radical equality. ${ }^{28}$

In Faith that Does Justice, published in 1977, Jesuit Father David Hollenbach describes the way in which the concept of social justice developed and is related to the Thomistic categories of distributive and commutative justice. Hollenbach first rearticulates the Thomistic categories according to a corrected version of the common good in which there is assumed radical equality and dignity among all human persons. He then describes the third "mode" of justice, which he calls social justice.

The third modality of justice (social) concerns institutionalized patterns of mutual action and interdependence which are necessary to bring about the realization of distributive justice...it refers to the obligations of all citizens to aid in the creation of patterns of societal organization and activity which are essential both for the protection of minimal

\footnotetext{
${ }^{27}$ Ibid., 100.

${ }^{28}$ See Pope Pius XI, Quadragesino Anno, $§ 57$, http://www.vatican.va/holy_father/pius_xi/encyclicals/documents /hf_p-xi_enc_19310515_quadragesimo-anno_en.html
} 
human rights and for the creation of mutuality and participation by all in social life...social justice is a political virtue. ${ }^{29}$

For Hollenbach, the virtue of social justice is a modality of the broader virtue in which the values of a specific conceptualization of the common good-based on radical equality - are practically applied to society through the critique of social structures. This is a clear shift in the understanding of justice. Despite the Thomistic framework in which this new virtue is described, it is not Aquinas' concept of justice as a virtue that perfects the will. In Hollenbach's view, social justice is the way in which the virtue of justice motivates prudential reasoning to act with a specific critical apparatus and with a specific egalitarian agenda.

In recent years the concept of social justice has become almost exclusively identified with a specific form of social critique in which the economic structures of society, and the legal and governmental apparatuses that support them, are evaluated and challenged according to a fundamental conviction of absolute equality of persons. This can be seen clearly in the statement of a recent General Congregation of the Society of Jesus:

The struggle for justice has a progressive and gradually unfolding historic character, as it confronts the changing needs of specific peoples, cultures, and times. Previous congregations have called attention to the need to work for structural changes in the socioeconomic and political orders as an important dimension of the promotion of justice. $^{30}$

In the decades following Hollenbach's definition, social justice became more intimately connected to a specific type of economic critique based on the communitarian principles of economics outlined by Taparelli and infused with a good dose of Marxist philosophy. Added to the mix was the concept of the preferential option for the poor by which the Christian is motivated to take deliberate action in support of the members or groups within a society that do not have equal access to goods and services.

\section{Conclusion}

Understanding the ethical patrimony of the Society of Jesus and Catholic theology in general, as well as engaging with the contemporary appropriations of natural law and virtue ethics, requires an understanding of Aquinas' ethical theory. If one is dedicated to the constellation of issues described as the "promotion of social justice" within a Catholic context, then it is helpful to understand how these issues fit into Aquinas' system. One will only be frustrated if one looks to Aquinas' theory of justice to find the theoretical framework upon which a commitment to social justice can stand. For Aquinas, the virtue of justice simply does not

\footnotetext{
${ }^{29}$ David Hollenbach, SJ, "Modern Catholic Teachings Concerning Justice," in Faith That Does Justice, ed. John C. Haughey, SJ (New York: Paulist Press, 1977), 220.

${ }^{30}$ Jesuit Life and Mission Today: The Decrees of the $31^{s t}-35^{\text {th }}$ General Congregations of the Society of Jesus, ed. John W. Padberg, SJ (Saint Louis: The Institute of Jesuit Sources, 2009), Decree 3, §54, 531. For the specific calls for structural change see GC 32, D4, nn. 20, 20; GC 33, D1, nn. 32, 46.
} 
possess the faculties to accomplish that which is outlined in contemporary social justice. However, Aquinas does provide a theoretical framework in which the goals of social justice can be advanced. Translating the contemporary commitment to social justice into Thomistic language produces the following plan of attack. First, the concepts of radical equality and individual rights can be articulated through theoretical reasoning. The common good must be described according to the new ideals. This will lead to a rearticulation of human nature such that the contemporary ideals find their place in the expression of the common good. Second, the new conception of human nature and the common good will give rise to the critique and restructuring of social and economic forces according to the new articulation. This is accomplished by practical reasoning operating through prudence. Third, the new social and economic structures will be impacted through an infusion of the virtue of charity by which the preferential option for the poor is made socially viable. Although the fundamentally conservative virtue of justice will assist in the commitment of theoretical reasoning to rearticulate the common good in a manner that suits contemporary ideals, and assist in motivating practical reason in pursuing means that will accomplish these ends, it is not the primary virtue in operation. Since the bulk of the issues involved in "promoting social justice" deals with critiquing and changing the practical social and economic realities, for a faith to effectively seek the promotion of justice, within the language of Aquinas, it must be a faith that acts with practical reasoning guided by prudence. 